\title{
Impact of Urban Sewage Water on Soil Properties in Guravarajupalle Village of Renigunta Mandal of Chittoor District in Andhra Pradesh, India
}

\author{
M. Harshitha*, A. Prasanthi, M.V.S. Naidu and S. Hemalatha
}

Department of Soil Science and Agricultural Chemistry, S. V. Agricultural College, Acharya N.G.Ranga Agricultural University, Tirupati - 517502, Andhra Pradesh, India

*Corresponding author

\section{A B S T R A C T}

\begin{tabular}{|l|}
\hline K e y w o r d s \\
$\begin{array}{l}\text { Soil properties, } \\
\text { Sewage water } \\
\text { irrigated soils and } \\
\text { Macronutrients }\end{array}$ \\
\hline Article Info \\
\hline $\begin{array}{l}\text { Accepted: } \\
\text { 26 June 2018 } \\
\text { Available Online: } \\
\text { 10 September } 2018\end{array}$ \\
\hline
\end{tabular}

\section{Introduction}

Water is becoming the most important limiting natural resource now-a-days and more than $70 \%$ of water is being utilized for irrigation. Shortage of surface and underground water could be partially overcome by reuse or recycling of sewage water and its multiple uses are becoming more and more important to meet the increased demand of agricultural production. Poor water quality degrades soil quality, results in the accumulation of heavy metals and alteration of soil physical, physicochemical and chemical properties and influences the soil health to a great extent.
However use of waste water as a supplemental source of irrigation is inevitable for increased agricultural production in many arid and semiarid regions where irrigation supplies are insufficient to meet crop water needs. A huge quantity of waste water is being generated from cities and other industrial areas which is flowing, to a river or joined with streams, towards the village where most of the people are earning their lively hood through agriculture. Most of the farmers, who have fields near the banks of these sewage canals are using this as a source of irrigation and pumping / flooding water directly to their field. It is being increasingly used for 
irrigation. Sewage water irrigation was noticed in Guravarajupalle village of Renigunta mandal of Chittoor district. To find out the impact of sewage water on soil physicchemical and chemical properties, the present investigation was taken up.

\section{Materials and Methods}

The study area Guravarajupalle village lies in between $13^{\circ} 38^{\prime} 6^{\prime \prime}$ to $13^{\circ} 38^{\prime} 45^{\prime \prime}$ of North latitudes and to $79^{\circ} 35^{\prime} 45^{\prime \prime}$ to $79^{\circ} 31^{\prime} 51^{\prime \prime}$ of East longitudes and the investigation was carried in the year 2017. One hundred samples were collected randomly from sewage irrigated soils of Guravarajupalle village of Renigunta mandal of Chittoor district. The soil samples after collection were air-dried, ground, screened through $2 \mathrm{~mm}$ sieve and stored in polythene covers for further analysis.

All the samples were analysed for $\mathrm{pH}, \mathrm{EC}$, organic carbon as per the standard procedures (Jackson, 1973). Available N was determined by alkaline permanganate method. The available $\mathrm{P}$ was extracted with the $0.5 \mathrm{M}$ $\mathrm{NaHCO}_{3}$ extractant and determined by using ascorbic acid as reducing agent and the available $\mathrm{K}$ and $\mathrm{Na}$ in the soils were extracted by employing neutral normal ammonium acetate and determined by aspirating the extract into the flame photometer whereas calcium and magnesium were extracted with neutral normal ammonium acetate and the content was determined by versenate titration method (Jackson, 1973).

\section{Results and Discussion}

\section{Soil pH, EC and organic carbon}

Soil reaction in the sewage water irrigated soils varied from slightly acidic to strongly alkaline ranging from 6.05 to 9.26 (Table 1). The variation in soil $\mathrm{pH}$ might be attributed by different factors like leaching action of water, soil nature and mechanical composition. The reason for low $\mathrm{pH}$ in some sewage water irrigated soils may be due to the decomposition of organic matter and production of organic acids (Alghobar and Suresha, 2016). The higher $\mathrm{pH}$ values could be ascribed to the large quantity of salts present in sewage effluents (Bhat et al, 2011).

The EC of the sewage water irrigated soils in Guravarajupalle village of Renigunta mandal in Chittoor district was ranged from 0.28 to $3.57 \mathrm{dSm}^{-1}$ with the mean value of $2.28 \mathrm{dSm}^{-1}$ (Table 1). The low EC in some soils may be due to flooding of fields. The fields when flooded continuously, there is downward movement of water to the lower horizons and soluble salts also move downward with this water, resulting in decrease of EC (Mehdi et al., 2003). High EC in some sewage water irrigated soils could be ascribed to the large amount of ionic substances and soluble salts, due to salt content of sewage water of domestic origin (Mojiri and Aziz, 2011).

The organic carbon content in the soils ranged from 0.21 to 0.92 per cent with a mean value of 0.54 per cent (Table 1). The low organic carbon of some soils could be ascribed to rapid decomposition of organic matter in semi-arid climatic conditions existing in the study area. The high organic carbon in most of the sewage irrigated soils is due to a very high organic load of sewage water (Singh et al., 2012) and also due to organic compounds of living beings in sewage effluent which are rapidly decomposed in the soil. Similar results were reported by and Salakinkop and Hunshal (2014).

\section{Available $\mathrm{N}, \mathrm{P}_{2} \mathrm{O}_{5}$ and $\mathrm{K}_{2} \mathrm{O}$}

The available nitrogen in sewage water irrigated soils ranged from 100.16 to 363.50 $\mathrm{kg} \mathrm{ha}^{-1}$ with the mean value of $205.25 \mathrm{~kg} \mathrm{ha}^{-1}$ (Table 1). The reason for low nitrogen in most 
of the soils might be due to alkaline conditions which were responsible for loss of nitrogen through mechanism like ammonia volatilization. These findings were supported by Datta and Buresh (1989). In some soils medium amount of available nitrogen ascribed to use of sewage water, which contains high amount of N (Rai et al., 2011).

The sewage water irrigated soils were low to high (Table 1) in available $\mathrm{P}_{2} \mathrm{O}_{5}$ (3.06 to $308.28 \mathrm{~kg} \mathrm{ha}^{-1}$ ) with the mean values of 148.18 $\mathrm{kg} \mathrm{ha}^{-1}$. The high amount of available $\mathrm{P}_{2} \mathrm{O}_{5}$ in majority of sewage irrigated soils might be due to continuous use of sewage water which contains phosphorous. This was corroborated with the findings of (Salakinkop and Hunshal 2014) Available potassium $\left(\mathrm{K}_{2} \mathrm{O}\right)$ of the soils under investigation was ranged from 42 to 515 $\mathrm{kg} \mathrm{ha}^{-1}$ with a mean value of $215 \mathrm{~kg} \mathrm{ha}^{-1}$ (Table 1). The high amount of potassium in the soils might me due to continuous application of sewage water (Kharche et al., 2011).

Table.1 Physico chemical properties of sewage irrigated soils of Guravarajupalle village of Renigunta mandal in Chittoor district

\begin{tabular}{|c|c|c|c|c|c|c|c|c|}
\hline S. No & $\mathrm{pH}$ & $\begin{array}{l}\mathrm{EC}(\mathrm{dS} \\
\left.\mathrm{m}^{-1}\right)\end{array}$ & $\begin{array}{l}\mathrm{OC} \\
(\%)\end{array}$ & $\begin{array}{l}\mathrm{N} \\
\left(\mathrm{kg} \mathrm{ha}^{-1}\right)\end{array}$ & $\begin{array}{l}\mathrm{P}_{2} \mathrm{O}_{5} \\
\left(\mathrm{~kg} \mathrm{ha}^{-1}\right)\end{array}$ & $\begin{array}{l}\mathrm{K}_{2} \mathrm{O} \\
\left(\mathrm{kg} \mathrm{ha}^{-1}\right)\end{array}$ & $\begin{array}{l}\mathrm{Ca} \\
{[\mathrm{cmol}} \\
\left(\mathrm{p}^{+}\right) \\
\left.\mathrm{kg}^{-1}\right]\end{array}$ & $\begin{array}{l}\mathrm{Mg} \\
{[\mathrm{cmol}} \\
\left(\mathrm{p}^{+}\right) \\
\left.\mathrm{kg}^{-1}\right]\end{array}$ \\
\hline 1 & 8.63 & 0.72 & 0.79 & 200.48 & 307.73 & 579.53 & 7.00 & 3.60 \\
\hline 2 & 8.23 & 1.67 & 0.80 & 225.56 & 256.42 & 325.92 & 9.60 & 4.40 \\
\hline 3 & 8.70 & 2.18 & 0.78 & 288.26 & 221.38 & 311.94 & 7.90 & 3.80 \\
\hline 4 & 8.37 & 1.29 & 0.77 & 175.40 & 275.75 & 298.23 & 8.20 & 3.90 \\
\hline 5 & 7.91 & 1.89 & 0.85 & 213.02 & 236.45 & 263.83 & 7.10 & 3.00 \\
\hline 6 & 8.47 & 2.09 & 0.76 & 238.10 & 308.28 & 312.48 & 8.80 & 4.20 \\
\hline 7 & 9.01 & 2.10 & 0.82 & 162.86 & 213.52 & 316.24 & 8.00 & 4.00 \\
\hline 8 & 8.68 & 1.79 & 0.89 & 187.94 & 149.01 & 458.71 & 3.60 & 2.50 \\
\hline 9 & 8.93 & 2.01 & 0.98 & 162.86 & 138.75 & 309.66 & 4.50 & 3.20 \\
\hline 10 & 9.12 & 2.24 & 0.78 & 187.94 & 262.32 & 337.88 & 5.30 & 3.40 \\
\hline 11 & 8.65 & 1.41 & 0.76 & 137.78 & 199.77 & 444.86 & 4.60 & 2.60 \\
\hline 12 & 8.31 & 2.36 & 0.57 & 162.86 & 130.34 & 395.00 & 5.00 & 2.80 \\
\hline 13 & 6.99 & 3.29 & 0.71 & 150.32 & 181.10 & 513.00 & 8.10 & 4.20 \\
\hline 14 & 9.03 & 2.25 & 0.69 & 200.48 & 169.20 & 367.18 & 7.60 & 3.50 \\
\hline 15 & 6.62 & 3.31 & 0.56 & 175.40 & 301.73 & 417.58 & 9.10 & 4.30 \\
\hline 16 & 6.41 & 3.25 & 0.53 & 137.78 & 124.23 & 355.22 & 4.40 & 2.00 \\
\hline 17 & 6.37 & 3.45 & 0.56 & 213.02 & 197.80 & 432.23 & 5.60 & 2.90 \\
\hline 18 & 7.04 & 3.48 & 0.52 & 162.86 & 195.73 & 279.01 & 4.10 & 1.80 \\
\hline 19 & 8.51 & 2.50 & 0.47 & 162.86 & 158.40 & 349.84 & 3.50 & 1.60 \\
\hline 20 & 8.86 & 2.05 & 0.75 & 187.94 & 296.05 & 406.29 & 7.10 & 3.30 \\
\hline 21 & 9.07 & 1.81 & 0.80 & 175.40 & 149.99 & 343.53 & 5.90 & 3.70 \\
\hline 22 & 9.09 & 2.60 & 0.52 & 238.10 & 95.52 & 361.94 & 7.50 & 3.60 \\
\hline 23 & 9.11 & 2.83 & 0.84 & 200.48 & 197.69 & 371.88 & 6.20 & 2.70 \\
\hline 24 & 9.00 & 2.19 & 0.84 & 175.40 & 164.95 & 413.82 & 5.40 & 2.80 \\
\hline 25 & 8.77 & 2.42 & 0.76 & 150.32 & 89.73 & 426.45 & 4.90 & 3.10 \\
\hline
\end{tabular}




\begin{tabular}{|c|c|c|c|c|c|c|c|c|}
\hline 26 & 9.17 & 2.07 & 0.55 & 275.72 & 59.49 & 554.40 & 5.10 & 2.40 \\
\hline 27 & 9.03 & 2.33 & 0.76 & 300.80 & 199.55 & 333.58 & 9.40 & 4.10 \\
\hline 28 & 8.66 & 2.39 & 0.79 & 313.34 & 90.71 & 539.21 & 10.20 & 4.50 \\
\hline 29 & 8.92 & 2.48 & 0.80 & 288.26 & 209.59 & 498.89 & 9.00 & 3.70 \\
\hline 30 & 8.30 & 1.08 & 0.81 & 275.72 & 209.59 & 488.14 & 10.50 & 4.60 \\
\hline 31 & 6.05 & 0.46 & 0.81 & 288.26 & 93.88 & 451.18 & 9.20 & 6.30 \\
\hline 32 & 8.22 & 1.99 & 0.76 & 338.42 & 175.75 & 299.44 & 5.40 & 2.10 \\
\hline 33 & 8.12 & 1.18 & 1.05 & 263.18 & 150.21 & 462.60 & 8.90 & 5.00 \\
\hline 34 & 6.98 & 0.94 & 0.76 & 250.64 & 167.78 & 347.02 & 4.80 & 2.20 \\
\hline 35 & 8.24 & 2.57 & 0.77 & 238.10 & 217.78 & 318.80 & 5.10 & 1.60 \\
\hline 36 & 8.15 & 0.58 & 0.83 & 275.72 & 113.53 & 440.97 & 8.60 & 4.80 \\
\hline 37 & 6.65 & 1.09 & 0.78 & 225.56 & 145.84 & 421.08 & 9.00 & 4.70 \\
\hline 38 & 6.80 & 0.85 & 0.77 & 112.70 & 160.58 & 385.32 & 4.60 & 2.50 \\
\hline 39 & 8.91 & 1.59 & 0.58 & 275.72 & 46.61 & 336.13 & 6.40 & 3.30 \\
\hline 40 & 8.79 & 3.00 & 0.52 & 200.48 & 124.12 & 466.77 & 3.20 & 1.80 \\
\hline 41 & 6.52 & 1.24 & 0.59 & 325.88 & 112.77 & 478.73 & 4.00 & 1.10 \\
\hline 42 & 8.40 & 2.46 & 0.49 & 150.32 & 206.86 & 383.17 & 11.00 & 5.60 \\
\hline 43 & 8.85 & 2.79 & 0.82 & 288.26 & 170.62 & 295.28 & 6.10 & 2.70 \\
\hline 44 & 8.48 & 1.71 & 0.73 & 112.70 & 291.47 & 351.72 & 11.50 & 7.00 \\
\hline 45 & 8.73 & 0.64 & 0.57 & 288.26 & 181.43 & 325.38 & 9.90 & 6.10 \\
\hline 46 & 8.55 & 0.28 & 0.76 & 263.18 & 133.72 & 351.72 & 7.90 & 4.10 \\
\hline 47 & 8.51 & 2.53 & 0.79 & 213.02 & 45.41 & 405.35 & 11.80 & 6.50 \\
\hline 48 & 8.77 & 1.05 & 0.79 & 275.72 & 164.29 & 379.68 & 10.20 & 5.90 \\
\hline 49 & 8.54 & 2.40 & 0.83 & 363.50 & 124.88 & 307.91 & 5.20 & 1.90 \\
\hline 50 & 8.49 & 0.34 & 1.12 & 263.18 & 18.67 & 415.56 & 6.30 & 2.80 \\
\hline 51 & 8.47 & 1.85 & 0.77 & 150.32 & 194.42 & 400.11 & 10.50 & 5.10 \\
\hline 52 & 8.60 & 1.91 & 0.46 & 125.24 & 183.28 & 297.16 & 9.70 & 4.00 \\
\hline 53 & 8.16 & 0.37 & 0.45 & 200.48 & 21.40 & 326.32 & 7.40 & 3.90 \\
\hline 54 & 8.41 & 2.94 & 0.54 & 288.26 & 110.15 & 277.13 & 11.20 & 5.20 \\
\hline 55 & 8.90 & 2.16 & 0.85 & 175.40 & 123.79 & 339.63 & 9.10 & 4.80 \\
\hline 56 & 8.50 & 2.21 & 0.53 & 187.94 & 166.04 & 338.28 & 10.10 & 5.30 \\
\hline 57 & 8.31 & 1.38 & 0.49 & 162.86 & 131.32 & 407.64 & 7.00 & 4.30 \\
\hline 58 & 8.09 & 1.76 & 0.48 & 137.78 & 248.24 & 258.45 & 6.50 & 4.20 \\
\hline 59 & 8.10 & 2.28 & 0.51 & 150.32 & 76.52 & 289.77 & 7.20 & 3.00 \\
\hline 60 & 8.17 & 1.95 & 0.58 & 325.88 & 68.23 & 418.92 & 8.10 & 4.50 \\
\hline 61 & 8.19 & 1.12 & 0.57 & 213.02 & 3.06 & 295.81 & 5.90 & 2.20 \\
\hline 62 & 8.03 & 2.17 & 0.56 & 200.48 & 109.16 & 267.05 & 8.00 & 4.40 \\
\hline 63 & 8.06 & 1.34 & 0.46 & 225.56 & 186.56 & 252.27 & 6.70 & 3.10 \\
\hline 64 & 9.25 & 3.15 & 0.46 & 275.72 & 45.85 & 155.23 & 6.00 & 4.30 \\
\hline 65 & 9.23 & 3.21 & 0.83 & 275.72 & 156.43 & 241.52 & 6.50 & 4.90 \\
\hline 66 & 8.56 & 2.65 & 0.69 & 137.78 & 162.54 & 424.44 & 8.30 & 5.00 \\
\hline 67 & 8.72 & 2.37 & 0.45 & 263.18 & 52.40 & 286.94 & 10.80 & 5.80 \\
\hline 68 & 9.02 & 3.06 & 1.08 & 125.24 & 148.90 & 446.61 & 9.90 & 5.40 \\
\hline 69 & 8.95 & 3.41 & 1.00 & 200.48 & 154.79 & 298.10 & 10.40 & 5.70 \\
\hline 70 & 7.97 & 2.34 & 0.46 & 162.86 & 67.68 & 245.41 & 9.50 & 5.30 \\
\hline
\end{tabular}




\begin{tabular}{|c|c|c|c|c|c|c|c|c|}
\hline 71 & 7.92 & 2.32 & 0.56 & 213.02 & 39.74 & 442.04 & 6.30 & 2.80 \\
\hline 72 & 8.93 & 2.75 & 0.51 & 137.78 & 28.38 & 274.44 & 6.40 & 3.20 \\
\hline 73 & 8.99 & 2.54 & 0.57 & 225.56 & 33.62 & 258.59 & 6.20 & 3.30 \\
\hline 74 & 8.76 & 3.35 & 0.88 & 275.72 & 47.49 & 203.35 & 7.70 & 4.80 \\
\hline 75 & 9.10 & 3.39 & 0.86 & 300.80 & 50.00 & 417.45 & 6.60 & 3.50 \\
\hline 76 & 9.26 & 3.52 & 0.94 & 250.64 & 161.45 & 225.52 & 7.30 & 3.80 \\
\hline 77 & 9.08 & 3.57 & 0.91 & 150.32 & 239.18 & 220.95 & 9.20 & 4.30 \\
\hline 78 & 8.78 & 2.67 & 0.59 & 238.10 & 247.04 & 306.70 & 5.80 & 2.80 \\
\hline 79 & 8.80 & 2.58 & 0.53 & 112.70 & 148.13 & 358.44 & 9.30 & 4.70 \\
\hline 80 & 9.11 & 2.85 & 0.78 & 162.86 & 264.28 & 374.84 & 7.10 & 4.00 \\
\hline 81 & 8.90 & 2.82 & 0.78 & 175.40 & 254.68 & 232.78 & 5.80 & 2.20 \\
\hline 82 & 8.65 & 2.47 & 0.53 & 338.42 & 239.18 & 378.34 & 6.90 & 3.50 \\
\hline 83 & 9.08 & 2.92 & 0.79 & 200.48 & 105.89 & 254.96 & 7.20 & 4.10 \\
\hline 84 & 8.94 & 2.49 & 0.93 & 300.80 & 44.10 & 258.05 & 6.90 & 3.40 \\
\hline 85 & 9.04 & 2.99 & 0.87 & 288.26 & 261.23 & 306.57 & 6.80 & 3.70 \\
\hline 86 & 8.99 & 2.98 & 1.10 & 275.72 & 101.63 & 137.22 & 10.40 & 6.00 \\
\hline 87 & 8.83 & 2.91 & 0.41 & 112.70 & 52.29 & 245.41 & 7.80 & 4.20 \\
\hline 88 & 9.02 & 2.89 & 0.42 & 125.24 & 45.96 & 205.90 & 8.50 & 5.40 \\
\hline 89 & 9.13 & 3.07 & 0.45 & 137.78 & 183.18 & 193.00 & 8.00 & 5.00 \\
\hline 90 & 9.09 & 2.69 & 0.54 & 162.86 & 177.94 & 233.18 & 9.20 & 4.30 \\
\hline 91 & 9.10 & 2.56 & 0.50 & 100.16 & 97.05 & 205.77 & 5.80 & 2.80 \\
\hline 92 & 8.91 & 3.05 & 0.61 & 125.24 & 85.69 & 215.17 & 5.90 & 2.90 \\
\hline 93 & 8.8 & 2.29 & 0.43 & 162.86 & 58.73 & 204.96 & 10.00 & 5.30 \\
\hline 94 & 8.76 & 3.18 & 0.39 & 137.78 & 37.22 & 195.55 & 5.80 & 2.40 \\
\hline 95 & 9.05 & 3.06 & 0.34 & 150.32 & 28.49 & 188.43 & 6.60 & 3.80 \\
\hline 96 & 8.92 & 3.12 & 0.40 & 175.40 & 128.81 & 182.11 & 7.40 & 3.60 \\
\hline 97 & 7.49 & 3.02 & 0.34 & 112.70 & 89.84 & 138.30 & 8.20 & 4.10 \\
\hline 98 & 8.52 & 3.19 & 0.35 & 162.86 & 234.92 & 166.12 & 5.70 & 2.80 \\
\hline 99 & 9.01 & 2.84 & 0.38 & 137.78 & 142.89 & 149.45 & 5.40 & 3.40 \\
\hline 100 & 8.42 & 2.95 & 0.52 & 125.24 & 141.69 & 187.35 & 4.90 & 2.90 \\
\hline Range & $\begin{array}{l}6.05- \\
9.26\end{array}$ & $\begin{array}{l}0.28- \\
3.57\end{array}$ & $\begin{array}{l}0.34- \\
1.12\end{array}$ & $\begin{array}{l}100.16- \\
363.50\end{array}$ & $\begin{array}{l}3.06- \\
308.28\end{array}$ & $\begin{array}{l}137.22- \\
579.53\end{array}$ & $\begin{array}{l}3.20- \\
11.8\end{array}$ & $\begin{array}{l}1.10- \\
7.00\end{array}$ \\
\hline Mean & 8.48 & 2.28 & 0.67 & 205.25 & 148.18 & 330.58 & 7.36 & 3.82 \\
\hline
\end{tabular}

\section{Available Ca and Mg}

The available calcium in sewage irrigated soils of Guravarajupalle village was ranged from 3.20 to $11.80 \mathrm{cmol}(\mathrm{p}+) \mathrm{kg}^{-1}$ soil (Table 1) with a mean value of $7.62 \mathrm{cmol}(\mathrm{p}+) \mathrm{kg}^{-1}$ soil. The high amount of calcium might be due to high calcium content of sewage water. Alghobar et al (2014) reported that soil is a biofilter that can reduce a large part of domestic waste water pollutants, but this filtering increased calcium content of soil.The available magnesium in sewage irrigated soils of Guravarajupalle village of Renigunta mandal in Chittoor district varied from 1.51 to $3.27 \mathrm{cmol}\left(\mathrm{p}+\mathrm{kg}^{-1}\right.$ soil with a mean value of $3.82 \mathrm{cmol}(\mathrm{p}+) \mathrm{kg}^{-1}$ soil (Table 1). The high available magnesium in sewage irrigated soils of the study area might be ascribed to high amount of magnesium in the sewage water. 
In conclusion, the sewage water irrigated soils of Guravarajupalle village of Renigunta mandal of Chittoor district varied from slightly acidic to strongly alkaline in reaction and non-saline to saline in nature, low to high in organic carbon. The macronutrients of analysed samples showed low to medium in available nitrogen, low to high in available $\mathrm{P}_{2} \mathrm{O}_{5}$ and $\mathrm{K}_{2} \mathrm{O}$. The available calcium and magnesium were found to be sufficient. Increased percentage of nutrients in soil can be noticed through sewage water irrigation in the study area.

\section{References}

Alghobar, M.A., Ramachandra, L and Suresha, S. 2014. Effect of sewage water irrigation on soil properties and evaluation of the accumulation of elements in Grass crop in Mysore city, Karnataka, India. Journal of Environmental Protection. (5): 283-291.

Alghobar, M.A. and Suresha, S. 2016. Effect of Wastewater Irrigation on Growth and Yield of Rice Crop and Uptake and Accumulation of Nutrient and Heavy Metals in Soil . Applied Ecology and Environmental Sciences, (3): 53-60.

Bhat, M.A., Agrawal, H.P., Wani, M.A and Wani, J.A. 2011. Long-term Effect of Sewage Water Irrigation on Heavy Metal Accumulation in Soils and Crops. Journal of the Indian Society of Soil Science. 59(1): 97-100.

Jackson, M.L. 1973. Soil Chemical Analysis. Oxford IBH Publishing House, Bombay. Pp. 38.

Jahantigh, M. 2008. Impact of Recycled Wastewater Irrigation on Soil Chemical
Properties in an Arid Region. Pakistan Journal of Biological Sciences. 11(18): 2264-2268.

Kharche, V.K., Desai, V.N and Pharande, A.L. 2011. Effect of sewage irrigation on soil properties, essential nutrient and pollutant element status of soils and plants in a vegetable growing area around Ahmednagar city in Maharashtra. Journal of the Indian Society of Soil Science. 59: 177-184.

Mojiri, A and Aziz, H.A. 2011. Effects of municipal waste water on Accumulation of heavy metals in soil and wheat (Triticum aestivum L.) with two irrigation methods. Romanian Agricultural Research. 28: 217-222.

Mehdi, S.M., Abbas, G., Sarfrz, M., Abbas, S.T. and Hassan, G. 2003. Effect of industrial effluents on mineral nutrition of rice and soil health. Pakistan Journal of Applied Sciences. 3(6): 462-473.

Singh, P.K., Deshbhratar, P.B and Ramteke, D.S. 2012. Effects of sewage wastewater irrigation on soil properties, crop yield and environment. Agricultural Water Management. 103: 100- 104.

Kordlaghari, K.P., Sisakht, S.N and Saleh, A. 2013. Soil chemical properties affected by application of treated municipal wastewater. Annals of Biological Research. 4 (3): 105-108.

Salakinkop, S.R and Hunshal, C.S. 2014. Domestic sewage irrigation on dynamics of nutrients and heavy metals in soil and wheat (Triticum aestivum L.) Production. Journal of Recycling Organic Waste Agriculture. 3: 1-8.

\section{How to cite this article:}

Harshitha, M.A. Prasanthi, M.V.S. Naidu and Hemalatha, S. 2018. Impact of Urban Sewage Water on Soil Properties in Guravarajupalle Village of Renigunta Mandal of Chittoor District in Andhra Pradesh, India. Int.J.Curr.Microbiol.App.Sci. 7(09): 3764-3769.

doi: https://doi.org/10.20546/ijcmas.2018.709.465 